\title{
Comparison of the continuous cell line 293 with human embryo kidney cells and human embryo fibroblast cells for the cultivation of ocular viruses
}

\author{
DL YIRRELL*†, APCH ROOME* \\ From the *Department of Virology, Bristol Royal Infirmary, Marlborough Street, Bristol BS2 8HW, the \\ $\dagger$ Department of Microbiology, University of Bristol, and the $\ddagger$ Bristol Public Health Laboratory, Myrtle Road, \\ Kingsdown, Bristol BS2 8EL
}

SUMMARY The continuous cell line 293 was evaluated as a replacement for primary human embryo kidney (HEK) cells in the cultivation of ocular viruses. The 293 cells were found to be as $\&$ sensitive as HEK cells and human embryo fibroblast (HEF) cells for the cultivation of adenovir- 9 uses and herpes simplex virus (HSV) respectively. As a continuous cell line, 293 cells are preferable to HEK and HEF cells for the routine isolation of ophthalmic viruses.

There has been much evidence since the 1960s that human embryo kidney (HEK) cells are the most sensitive culture system for the isolation of the non-enteric adenoviruses. ${ }^{1-4}$ Not only do HEK cells produce higher end-point titres for many adenovirus serotypes than do other cells, but also, if titres are comparable, the onset of cytopathic effect is more rapid. However, the availability of HEK cells depends upon a supply of fresh human embryos from terminated pregnancies, and this material can be very difficult to obtain.

Graham et $a l^{5}$ treated HEK cells with sheared fragments of adenovirus type 5 DNA, producing the transformed cell line 293. Since this line could be superinfected with a number of conventional human adenoviruses, including the fastidious type 12 , they suggested that 293 cells would be useful in the study of adenoviruses.

Therefore, 293 cells were evaluated as possible replacements for HEK cells in the isolation of conventional adenoviruses from the eye. Furthermore, since herpes simplex virus (HSV) accounts for a large proportion of viral ocular infections, the susceptibility of 293 cells to this virus was compared with that of human embryo fibroblast (HEF) cells, the cells used in our laboratory for the routine isolation of HSV.

The lines of investigation pursued were:

1 A retrospective study in which clinical specimens

Accepted for publication 27 April 1983 previously found to contain adenovirus and stored at $-70^{\circ} \mathrm{C}$ were inoculated into 293 cells.

2 The titration of selected adenovirus serotypes 解离 both HEK and 293 cells in order to compare the time taken for cytopathic effect to appear, the entes point titres and the time taken to reach those titres. 3 A retrospective study in which specimens previously found to contain HSV were inoculated into 293 and HEF cells.

4 The titration of several isolates of HSV in 293 and HEF cells.

5 A prospective study by the addition of 293 cells to the routine range of cell cultures used in the isolation of ocular viruses in our laboratory.

\section{Material and methods}

CELLS

Primary human embryo kidney (HEK)

HEK cells were prepared by the overnight digestion at $4^{\circ} \mathrm{C}$ followed by one-hour digestion at $37^{\circ} \mathrm{C}$ of fresh human embryo kidneys with $0.05 \%$ collagenase (Sigma) and $0.25 \%$ trypsin (Flow). The cells $\sigma$ were washed twice in Eagle's MEM and then seeded $N$ in 0.5 inch $(12.5 \mathrm{~mm})$ tubes in $0.5 \mathrm{ml}$ Eagle's MEM N (Flow) containing $8 \%$ fetal calf serum (FCS), $2 \mathrm{mmol} / \mathrm{l}$ glutamine (Flow) $0.176 \%$ sodium bicarbonate and SPA (streptomycin $100 \mu \mathrm{g} / \mathrm{ml}$, penicillin $60 \mu \mathrm{g} / \mathrm{ml}$, aerosporin $50 \mathrm{IU} / \mathrm{ml}$ ). On reaching $\stackrel{?}{?}$ confluence the cells were maintained in $1 \mathrm{ml}$ of the above medium with only $2 \%$ FCS and with $2.5 \mathrm{IU} /$ $\mathrm{ml}$ fungizone. 
Secondary human embryo fibroblasts (HEF)

HEF cells were prepared from human embryo skin by the same digestion method used for HEK cells and were seeded into bottles. They were subsequently removed by trypsinisation and transferred to tubes. The medium used was as above but containing only $0 \cdot 132 \%$ sodium bicarbonate.

\section{3 cells}

293 cells (Flow) were grown to confluence in tubes in $0.5 \mathrm{ml}$ volumes of Eagle's MEM containing $8 \%$ new-born calf serum (NCS), $4 \%$ FCS, $0.176 \%$ sodium bicarbonate, $2 \mathrm{mmol} / \mathrm{l}$ glutamine and SPA. The cells were maintained in $1 \mathrm{ml}$ of the same medium with only $2 \% \mathrm{FCS}$ and with $2.5 \mathrm{IU} / \mathrm{ml}$ fungizone.

All cell lines were incubated at $37^{\circ} \mathrm{C}$ and maintenance medium was changed twice weekly. After inoculation all tubes were incubated in a roller drum with the exception of those containing 293 cells which grow better when stationary. When cells were grown in 96 well microculture trays (Linbro) $0.2 \mathrm{ml}$ of the relevant growth and maintenance media were used, and the trays were incubated in $5 \% \mathrm{CO}_{2}$ in air.

\section{CLINICAL SPECIMENS}

Clinical specimens were obtained from Bristol and Gloucester Public Health Laboratories (PHL), Bristol Eye Hospital Casualty Department and the Bristol Royal Infirmary Genitourinary Department.

Eye, throat and genital specimens were taken by swabbing with cotton wool tipped swabs which were placed in bijou bottles containing $4 \mathrm{ml}$ milk saline transport medium $(20 \mathrm{~g}$ skimmed milk powder (Oxoid), $200 \mathrm{ml}$ deionised water and $200 \mathrm{ml}$ PBS A (Dulbecco)). Faecal emulsions $(10 \%)$ were made in Eagle's MEM (Gibco) containing $0.5 \%$ lactalbumin hydrolysate (Gibco), $0.176 \%$ sodium bicarbonate and double strength SPA. Specimens were then stored at $4^{\circ} \mathrm{C}$ until inoculated $(0.2 \mathrm{ml})$ into cell cultures the same day. After inoculation the specimens were snap frozen and stored at $-70^{\circ} \mathrm{C}$.

\section{RETROSPECTIVE STUDIES}

Eighty-eight clinical specimens ( 71 ocular, 9 throat, 8 faecal) which had previously been found positive for adenovirus in the cell lines used for routine isolation (HEp 2, HEK and HEF) were inoculated $(0.2 \mathrm{ml})$ into duplicate tubes of 293 cells and when possible in parallel in HEK cells. These consisted of adenovirus type 1 (18 isolates), type 2 (21), type 3 (10), type $3 / 4(6)$, type $7(16)$, type $8(1)$, type $9(1)$, type $11(15)$.

Thirty clinical specimens (15 ocular, 15 genital) which had previously been found to contain herpes simplex virus by isolation in routine cell lines
(HEp 2, HEK and HEF) were inoculated $(0.2 \mathrm{ml})$ in parallel in duplicate tubes of 293 and HEF cells.

\section{TITRATIONS}

Adenovirus titrations were carried out on primary isolates from our own laboratory and from the Bristol PHL. These had been isolated in HEK cells and then typed by neutralisation. Serial tenfold dilutions of the isolates were made in HEK maintenance medium and $0.2 \mathrm{ml}$ of each was inoculated into HEK and 293 tubes, usually in triplicate. The cells were examined for cytopathic effect daily for a period of 28 days although no positives were recorded after 18 days for either cell line or any adenovirus serotype.

HSV titrations were carried out on primary isolates. Both ocular (5) and genital (4) isolates were used to make probable the inclusion of both HSV types. Titrations were carried out on isolates made in a variety of cell types (HEp 2 [3], HEF [2], 293 [3], HEK [1]) to avoid bias due to cell line adaptation. Tenfold dilutions of virus were made in HEK maintenance medium and $0 \cdot 1 \mathrm{ml}$ of each was inoculated, usually in quadruplicate, into HEF and 293 cells in wells of a microculture plate. The cells were examined daily for 12 days for cytopathic effect although no positives were recorded after day 7 .

\section{ROUTINE USE}

For a period of seven months 293 cells were included with the other cell lines (HEp 2 and HEF, and HEK when available) for the routine isolation of viruses from eye swabs. Adenovirus isolates were typed by neutralisation and $\mathrm{HSV}$ isolates were confirmed as such by immunofluorescence.

\section{Results}

\section{RETROSPECTIVE ADENOVIRUS STUDY}

Adenovirus was recovered in 293 cells from all of the 88 positive specimens whereas in HEK cells it was recovered from 86 . The latter failed to grow one adenovirus type 1 (faeces) and one type 2 (throat). In 293 cells cytopathic effect generally took less than five days to appear, whereas in HEK cells it was rarely observed before this time.

\section{ADENOVIRUS TITRATIONS}

All serotypes tested reached essentially the same end-point whether titrated on HEK or 293 cells, although the time taken to reach the end-point varied (Table 1).

\section{RETROSPECTIVE HSV STUDY}

The isolation rate in 293 s was $15 / 15$ for genital specimens and $13 / 15$ for eye swabs. This compared 
Table $1 T C D_{50}{ }^{*}$ of ten adenovirus serotypes in $H E K$ and 293 cells

\begin{tabular}{llllc}
\hline & \multicolumn{2}{c}{$T C D_{\text {so }}$} & \multicolumn{2}{c}{ Days to end-point } \\
\cline { 2 - 5 } Adenovirus type & $H E K$ & 293 & $H E K$ & 293 \\
\hline 1 & $7 \cdot 5$ & $8 \cdot 5$ & 12 & 9 \\
2 & 7 & $7 \cdot 5$ & 12 & 7 \\
3 & 8 & $8 \cdot 5$ & 14 & 17 \\
4 & 7 & $6 \cdot 5$ & 17 & 17 \\
5 & 9 & 9 & 17 & 12 \\
6 & $8 \cdot 5$ & $9 \cdot 5$ & 12 & 15 \\
7 & 7 & $6 \cdot 5$ & 10 & 12 \\
7 a & 8 & $8 \cdot 5$ & 9 & 14 \\
8 & $4 \cdot 5$ & $4 \cdot 5$ & 10 & 16 \\
37 & $4 \cdot 5$ & $4 \cdot 5$ & 12 & 12 \\
\hline
\end{tabular}

${ }^{*} \mathrm{TCD}_{30}$ expressed as $\log _{10}$ of the reciprocal of the dilution and calculated by the method of Kärber ${ }^{6}$

with the rate in HEF cells of $13 / 15$ for genital swabs and 9/15 for eye swabs. In 293 cells cytopathic effect was generally first observed two or three days after infection, whereas in HEF cells it was not seen until 3-6 days. Those specimens which were positive in 293 cells but negative in HEF cells produced cytopathic effect 3-9 days after infection.

\section{HERPES SIMPLEX VIRUS TITRATIONS}

With the exception of two strains, all isolates of HSV tested reached essentially the same end-point whether titrated on HEF or 293 cells although the time taken to reach the end-point varied (Table 2).

\section{ROUTINE USE}

To date a total of 17 herpes simplex viruses and 22 adenoviruses (types 8 (3), 3/4 (6), 7 (5), 4 (2) and untyped (6)) have been isolated. 293 cells grew all viruses that were isolated. The other routine cell lines grew all of the adenoviruses but failed to isolate four HSV strains.

\section{Discussion}

In a recent study on the primary isolation of ophthalmic viruses ${ }^{4}$ the need for a continuous cell line as

Table $2 T C D_{\text {so }}$ of nine HSV isolates in HEF and 293 cells

\begin{tabular}{|c|c|c|c|c|c|}
\hline \multicolumn{2}{|c|}{ HSV isolated } & \multicolumn{2}{|c|}{$T C D_{50}$} & \multicolumn{2}{|c|}{ Days to end-point } \\
\hline From (site) & In (cells) & $H E F$ & 293 & $H E F$ & 293 \\
\hline $\begin{array}{l}\text { Genital } \\
\text { Eye } \\
\text { Genital } \\
\text { Genital } \\
\text { Genital } \\
\text { Eye } \\
\text { Eye } \\
\text { Eye } \\
\text { Eye }\end{array}$ & $\begin{array}{l}293 \\
293 \\
\text { HEF } \\
\text { HEF } \\
\text { HEK } \\
\text { HEp 2 } \\
\text { HEp 2 } \\
\text { HEp } 2 \\
293\end{array}$ & $\begin{array}{l}3 \cdot 5 \\
5 \cdot 5 \\
3 \\
5 \cdot 5 \\
5 \cdot 5 \\
4 \cdot 5 \\
4 \cdot 5 \\
6 \\
1 \cdot 5\end{array}$ & $\begin{array}{l}4 \\
5 \cdot 5 \\
3 \\
5 \cdot 5 \\
5 \cdot 5 \\
4 \cdot 5 \\
5 \\
8 \\
3\end{array}$ & $\begin{array}{l}3 \\
6 \\
3 \\
3 \\
6 \\
3 \\
3 \\
3 \\
4 \\
4\end{array}$ & $\begin{array}{l}3 \\
6 \\
6 \\
6 \\
3 \\
6 \\
6 \\
7 \\
7 \\
7\end{array}$ \\
\hline
\end{tabular}

sensitive as HEK cells was clearly stated. This study shows that the cell line 293 fulfils this requirement.

The suitability of 293 cells for the cultivation of

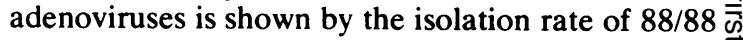
recorded in them compared with that of $86 / 88$ 음 recorded in HEK cells when both were inoculated $\overline{0}$ with the same adenovirus positive clinical speci- $\frac{\bar{m}}{\vec{D}}$ mens. While the difference of two cannot be $\stackrel{\mathbb{D}}{\circ}$ regarded as a significant improvement over HEK cells, it must be noted that when a direct comparison ${ }^{\circ}$ between the two cell types was not possible, speci- $\overrightarrow{0}$ mens were subjected to an additional freeze/thawing $\vec{\overrightarrow{ }}$ before inoculation into 293 cells, which effectively biased the results in favour of HEK cells.

Further evidence of the value of 293 cells is provided by the adenovirus titrations in which 293 and HEK cells are compared. The results (Table 1) indicate that the time taken to reach the end-point and $ळ$ indeed the end-point titre itself to be very similar for 0 the two cell types and within the bounds of experimental variation.

Similarly, the suitability of 293 cells for the culti- $\frac{\mathbb{D}}{O}$ vation of HSV is shown by the isolation rates $\left(293 \frac{\mathbb{D}}{3}\right.$ [28/30], HEF [22/30]) for clinical specimens con- 응 taining HSV. The isolation rate was lower for stored $\stackrel{\Phi}{-}$ HSV than for adenoviruses which were kept under $\overrightarrow{0}$ the same conditions. Since all HSV-positive speç्ठ mens had had virus isolated in HEF cells prior storage this indicates a reduction in viral titre due HSV lability.

The results of the HSV titrations (Table 2) show 293 cells to be at least as sensitive to HSV as are $\frac{\circ}{\varnothing}$ HEF cells. No obvious bias due to cell line adaptation was observed.

Final proof of the suitability of 293 cells for the cultivation of adenoviruses and HSV from ocular specimens is provided by the results of their trial use in routine isolation. Since they were included they have grown all 39 viruses isolated.

The use of 293 cells for the isolation of adenoviruses may be questioned on the grounds that reacti- $\delta$ vation of or recombination with the adenovirus type 5 genome may take place. However, there is no evi- o dence from restriction endonuclease analysis ${ }^{7}$ (JM Darville, personal communication 1983) that either event occurs and in any case the cells contain only about $22 \%$ of the viral genome ${ }^{5}$. Furthermore, none $\sigma$ of the adenoviruses isolated during the routine use $N$ of 293 cells proved to be type 5 .

In conclusion, although 293 cells have not been shown to be more sensitive to ocular adenoviruses than are HEK cells, the two cell types are directly comparable. Additionally, it has been shown that $\stackrel{\oplus}{\oplus}$ 293 cells grow HSV as well as do HEF cells. From 0 the evidence presented, it is clear that 293 cells have retained the sensitivity of their parent cell type to 
adenoviruses and to HSV, whilst gaining the advantages, such as ease of supply and maintenance, associated with a continuous cell line. Therefore, 293 cells are a suitable alternative to HEK and HEF cells in the routine isolation of ocular viruses.

We wish to thank Serono UK Ltd for funding this research, Dr Ellis J Snitcher of Serono for his interest in the work and Flow Labs Ltd for advice and help with the 293 cells. We also thank Professor DL Easty and Dr D Jones of the Bristol Eye Hospital, Dr SKR Clarke of Bristol PHL and Dr KW Cartwright of Gloucester PHL for the provision of the specimens.

\section{References}

' Wigand R, Schulz R. Laboratory procedures in adenoviruses II. Sensitivity of various cell cultures as determined by endpoint titration. Zentralbl Bakteriol [Orig A] 1975;231:31-41.

${ }^{2}$ Kasel JA. Adenoviruses. In: Lennette EH, Schmidt NJ, eds.
Diagnostic procedures for viral, rickettsial and chlamydial infections. 5th ed. Washington DC: American Public Health Association, 1979:229-55.

${ }^{3}$ McSwiggan DA, Darougar S, Rahman AFMS, Gibson JA. Comparison of the sensitivity of human embryo kidney cells, HeLa cells, and WI38 cells for the primary isolation of viruses from the eye. J Clin Pathol 1975;28:410-3.

4 Cubitt WD, McSwiggan DA, Thaker U, Darougar S. A comparison of the efficiency of human embryo intestine, HEp 2 cells, and human embryo kidney cells for the primary isolation of ophthalmic viruses. Br J Ophthalmol 1981;65:546-8.

${ }^{5}$ Graham FL, Smiley J, Russell WC, Nairn R. Characteristics of a human cell line transformed by DNA from human adenovirus type 5. J Gen Virol 1977;36:59-72.

- Kärber G. Beitrag zur kollektiven Behandlung pharmakologischer Reihenversuche. Arch Exp Pathol Pharmakol 1931;162:480-3.

'Takiff HE, Straus SE, Garon CF. Propagation and in vitro studies of previously non-cultivable enteral adenoviruses in 293 cells. Lancet 1981 ;ii:832-4.

Requests for reprints to: Mr DL Yirrell, Department of Virology, Bristol Royal Infirmary, Marlborough Street, Bristol BS2 8HW, England. 